\title{
A matrix population model for the hawksbill sea turtle (Eretmochelys imbricata) in the Gulf of Paria, Venezuela
}

\author{
Clemente Balladares ${ }^{1,2}$, María Fernanda Gonzalez ${ }^{1} \&$ Diego Rodriguez ${ }^{2}$ \\ ${ }^{1}$ Dirección General de Diversidad Biológica, Ministerio del Ambiente Venezolano (MinEC) \\ Caracas, Venezuela \\ ${ }^{2}$ Instituto de Zoología y Ecología Tropical (IZET), Universidad Central de Venezuela \\ Caracas, Venezuela \\ Corresponding author: Clemente Balladares (cballadares86@gmail.com)
}

\begin{abstract}
Following classical literature in herpetology, we built two five-stage life tables for the endangered hawksbill sea turtle Eretmochelys imbricata in the Gulf of Paria, eastern Venezuela, using data from incidental captures by industrial trawl fisheries from 1991 until 2000, artisanal fisheries effect and regional stranding from 1999 to 2017, and a local conservation project with the nesting females from 2003 to 2018. We estimated the survivorship for the managed, translocated nests, and a portion of the natural in situ nests $(\approx 31 \%)$. We used the resultant life graph and matrices to estimate the hawksbills population status in the region and determine differences in population growth rate and elasticity between translocated and in situ nests. Eggs/hatchlings (stage 1) and small juveniles of less than three years old (stage 2), had high mortalities. We controlled stage 1 mortality by translocating nests into a hatchery. The in situ nests suffered almost $88 \%$ predation or poaching. Conversely, these non-translocated nests' emergence success was greater than that of managed nests, but overall survivorship was the lower. We propose that fecundity could begin with sub-adults (stage 4) after the $7^{\text {th }}$ year with $60 \mathrm{~cm}$ of curved carapace length. Finite rates of increase of both populations, managed and natural, were significantly higher than 1, and that of the managed population is significantly higher than that of the natural one, meaning that both populations would grow and that the managed one would grow faster than the natural one. Then protection of stage 1 is essential to the population of hawksbills in the region, although uncertainties of survivorship of stage 2 and fecundity of stage 4 were not properly confirmed locally. Notwithstanding, elasticity analysis indicated that the population growth rate was more affected by proportional changes in sub-adults and adults' fecundity than any other life-history element.
\end{abstract}

Keywords: Eretmochelys imbricata; hawksbill; fecundity; human interventions; life tables; survivorship; Caribbean

\section{INTRODUCTION}

As in all animal populations, survivorship and fecundity are the necessary data required to construct life tables. The analysis of population matrices containing these data allows environmental managers to design strategic conservation policies, particularly for threatened species such as sea turtles (Heppel et al., 1996; Morris et al., 2011; Herrera et al., 2012). In 1983, Frazer (1983) estimated survivorship of adult female loggerhead sea turtles (Caretta caretta) nesting on an island in Georgia, USA. Later, Frazer \& Ehrhart (1985) developed growth models for the same species and the green turtle (Chelonia mydas), while Crouse et al. (1987) built a seven-stage matrix model for loggerhead sea turtles to evaluate management options and data requirements for this species. Crowder et al. (1994) rebuilt this matrix with five stages to consider incidental fisheries' impact on the sea turtle populations off the USA's southeastern coasts.

The hawksbill turtle (Eretmochelys imbricata) is a worldwide critically endangered species (Mortimer \& Donnelly, 2008). In the second decade of the $21^{\text {st }}$ century, hawksbills are still used by humans for meat, eggs, the whole body as decoration, and especially for the carapace scutes (Barrios-Garrido et al., 2017). To manage the hawksbill populations of the Caribbean Sea, Crouse (1999) proposed a growth model similar to

Corresponding editor: Joanna Alfaro 
the one proposed for loggerhead and green turtles, but without designing a life table due to the lack of sufficient data at that time. However, with the available information on growth and fecundity, she cautiously suggested protecting all life stages.

In the last 20 years, significant advances have been achieved in the knowledge for hawksbill biology and ecology, especially regarding population trends (Richardson et al., 2006; Begg et al., 2007; Hamilton et al., 2015), hatchling survival (Harewood \& Horrock, 2008), dispersal patterns (Hawkes et al., 2012; Moncada et al., 2012), and growth rates estimation (Kobayashi, 2000; Gorham et al., 2014; Hawkes et al., 2014). This information can enable a better estimation of survivorship and fecundity of this species.

Here, we propose a five-stage matrix population growth model for a small hawksbill turtle population located at the Gulf of Paria, eastern Venezuela. This population has been under different natural and anthropogenic stressors for almost 27 years, by industrial and artisanal fishing in the area. We used this model to evaluate conservation efforts' effectiveness since the beginning of the project in 2003, which we hypothesized affected the survivorship and fecundity of this species.

\section{MATERIALS AND METHODS}

\section{Study site}

The Gulf of Paria is an estuarine region south of the Paria Peninsula in Sucre State, Venezuela. Further south is the Orinoco River Delta, and to the east is the island country of Trinidad and Tobago (Fig. 1). This Gulf has an average depth of $20 \mathrm{~m}$, with anticyclonic local sea currents, salinity ranges from 11 to 36 parts per thousand, and sea surface temperatures from 26 to $28^{\circ} \mathrm{C}$ (Rincón et al., 2008).

In the northeast part of the Gulf are several small beaches in the footsteps of the Parian Mountains. The main nesting beaches are: 1) Macurito, 2) Los Garzos, 3) Silvano, 4) Obispo and 5) Cerezo (Fig. 1, Balladares et al., 2010). Due to the steep hills, the beaches are very small; each beach is less than $300 \mathrm{~m}$ long and $75 \mathrm{~m}$ wide. These fives beaches are sandy with low berms and covered with supra-littoral vegetation, including the manchineel tree (Hippomane mancinella) and Portia tree (Thespesia populnea) (Balladares et al., 2010). These characteristics are ideal nesting conditions for hawksbills (Eretmochelys imbricata) in the region (Balladares \& Dubois, 2014). Los Garzos, Silvano, Obispo, and Cerezo are inside the Peninsula de Paria National Park, while Macurito is outside the park and near the fishing town of Macuro.

\section{Fieldwork}

We conducted surveys of the two main nesting beaches, Los Garzos and Macurito beaches, from mid-March until the end of October from 2003 to 2018. Starting in 2007, we included surveys at Silvano, Obispo, and Cerezo (also called Manzanillo; Fig. 1). Nocturnal and diurnal surveys were conducted four times per week by at least two local and trained patrollers. Surveyors identified all emerging female hawksbills and measured, photographed, and flipper tagged each turtle when possible following standard nesting monitoring protocols (Eckert et al., 2000).

We characterized the fate of each attempted nesting event (i.e., eggs harvested or not). Starting in 2006, we relocated presumably all hawksbill nests from their beaches to a secure hatchery in Macuro to avoid predation and poaching, and we referred those as our "managed nests." No translocations were conducted in 2012, 2017, and 2018 due to the hatchery's upgrading, so nests were left in situ. Nests were left in situ during other seasons (i.e., 2013, 2014, and 2015) and were included in the data set as "unmanaged or in situ/natural nests." We excavated each nest, translocated or not, after around 55 days of incubation to assess nest productivity. For managed and in situ nests, emerged hatchlings were counted before being released at the original beaches. Emergence success was calculated as the number of live emerged hatchlings from the nests divided by the total number of eggs laid for both kinds of nests. We aimed to compare 'managed' versus 'unmanaged or in situ' nests to assess conservation efforts' effect.

\section{Matrix population design}

We considered five stages in the hawksbill population of Paria Gulf according to sizes and an approximation of age classes, using as references Witzell (1983), Van Dam \& Diez (1998), and Limpus (2000). Stage 1 includes eggs and hatchlings $(<4 \mathrm{~cm}$ CCL, curved carapace length); stage 2 is small juveniles $(4.1-9.9 \mathrm{~cm}$ CCL); stage 3 is large juveniles (10-59.9 cm CCL), stage 4 is sub-adults (60-79.9 cm CCL), and stage 5 is adults (>80 cm CCL) (see details in Table 1). The results in the life cycle are shown in Figure 2. Following traditional matrix population growth models (Caswell, 2001), if we assume that the number of female individuals in the five stages at year $t$ are $n_{1, t}$, $n_{2, t}, n_{3, t}, n_{4, t}$ and $n_{5, t}$, and the census of individuals is made after breeding, the size of the population at the next time step can be represented with the Equation 1.

$$
\left(\begin{array}{l}
\mathrm{n}_{1, \mathrm{t}+1} \\
\mathrm{n}_{2, \mathrm{t}+1} \\
\mathrm{n}_{3, \mathrm{t}+1} \\
\mathrm{n}_{4, \mathrm{t}+1} \\
\mathrm{n}_{5, \mathrm{t}+1}
\end{array}\right)=\left(\begin{array}{ccccc}
0 & 0 & 0 & \mathrm{~F}_{4} & \mathrm{~F}_{5} \\
\mathrm{G}_{1} & \mathrm{P}_{2} & 0 & 0 & 0 \\
0 & \mathrm{G}_{2} & \mathrm{P}_{3} & 0 & 0 \\
0 & 0 & \mathrm{G}_{3} & \mathrm{P}_{4} & 0 \\
0 & 0 & 0 & \mathrm{G}_{4} & \mathrm{P}_{5}
\end{array}\right) \times\left(\begin{array}{l}
\mathrm{n}_{1, \mathrm{t}} \\
\mathrm{n}_{2, \mathrm{t}} \\
\mathrm{n}_{3, \mathrm{t}} \\
\mathrm{n}_{4, \mathrm{t}} \\
\mathrm{n}_{5, \mathrm{t}}
\end{array}\right)
$$




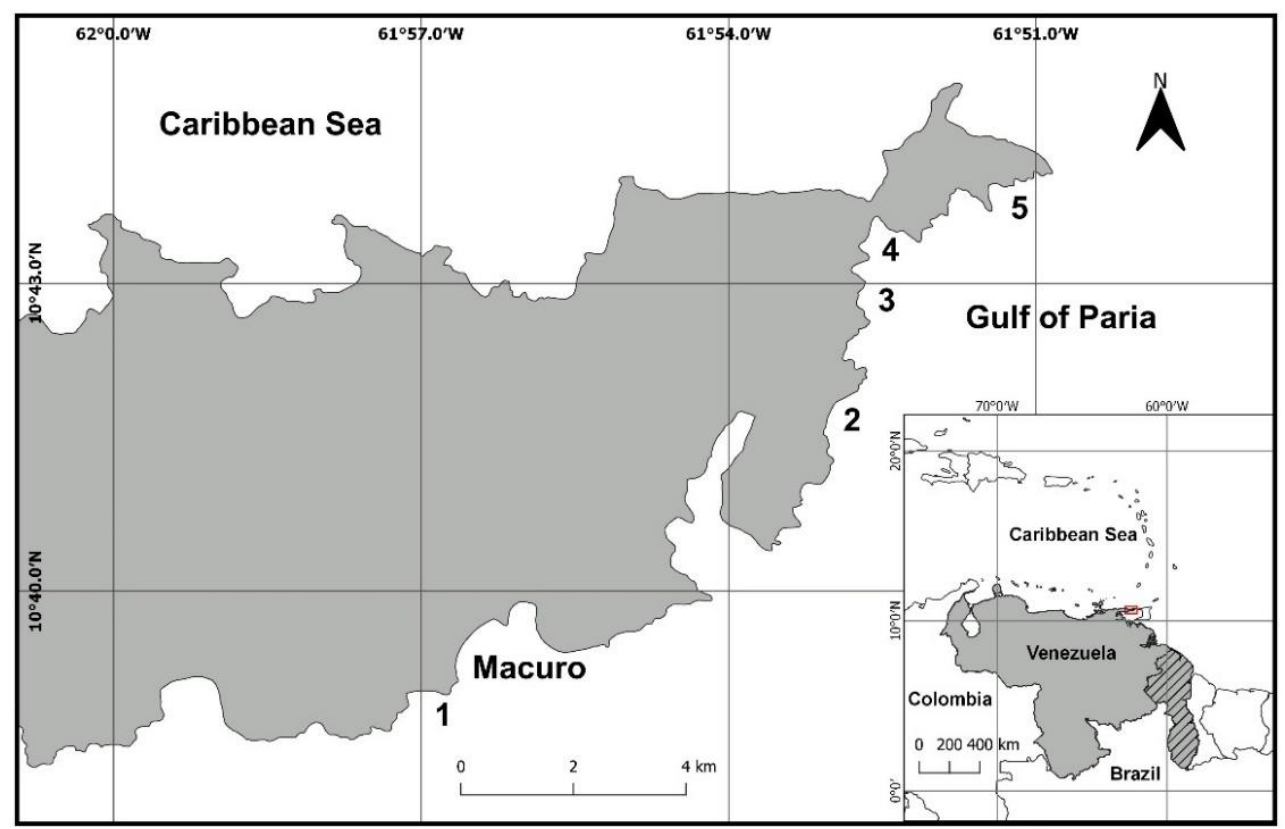

Figure 1. Location of the main nesting beaches at the Paria Gulf, Venezuela. 1. Macurito, 2. Los Garzos, 3. Silvano, 4. Obispo, and 5. Cerezo.

Table 1. Five age stages were proposed for the Gulf of Paria's hawksbill Eretmochelys imbricata population.

\begin{tabular}{llc}
\hline Stage & Year & $\begin{array}{c}\text { Curved carapace } \\
\text { length }(\mathrm{cm})\end{array}$ \\
\hline 1. Eggs/hatchlings & $<1$ & $<4$ \\
2. Small juveniles & $1-3$ & $4.1-9.9$ \\
3. Large juveniles & $3-7$ & $10-59.9$ \\
4. Sub-adults & $7-15$ & $60-79.9$ \\
5. Adults & $>15$ & $>80$ \\
\hline
\end{tabular}

where $P_{i}$ is the probability that an individual in stage $i$ survives and stays in the same stage through the next year, $G_{i}$ is the probability that an individual in stage $i$ survives and moves into the following stage the next year, and $F_{i}$ is the fecundity of females, that is to say, the number of newborns that appear in the next timestep per female in the current time step.

We estimated annual survivorships for the last three stages of the model using annual mortality data from incidental takes at the regional industrial trawl fishery from 1991 to 2000 (Alió et al., 2010) - in 2002. The industrial trawling fishery was legally forbidden in Venezuela by a National Decree, in addition to our data of artisanal fisheries and 136 stranded sea turtles registered from 1999 to 2017 (Official Stranding Record, Venezuelan Ministry of Environment, unpubl. data). Hawksbill bycatch mortality in the fisheries was estimated proportionally for the last three stages captured and added to the correspondent stranded stage

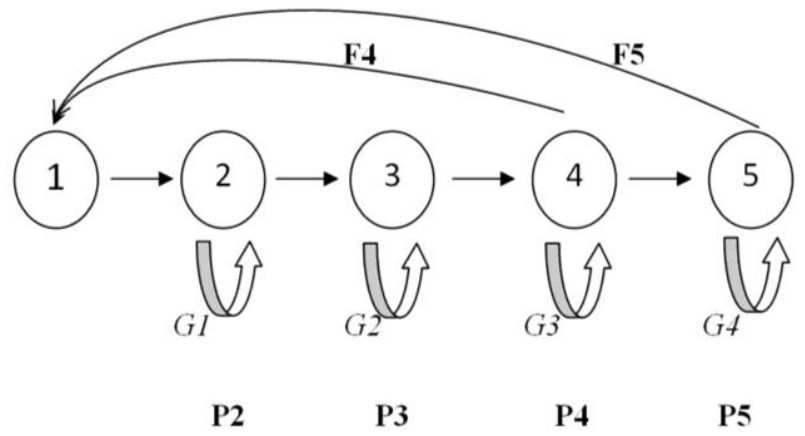

Figure 2. Corresponding life cycle graph for managed hawksbill Eretmochelys imbricata in the Gulf of Paria. Pi: probability to survive and maintain at the same stage. Gi: the probability that an individual past to the next stage. Fi: fecundity value.

fraction. Those calculations are considered minimum estimates of the occurred mortality for hawksbills in the Gulf of Paria's surrounding area. For stage 1, we used our field data of emergence success per poaching percentage, and for stage 2 , we assumed the smaller percentage from Harewood \& Horrock (2008), not the overall predation rate (see details in Table 2).

We used the Caswell (2001) method to obtain the elements of the transition matrix $A$ of Equation 1. This method assumes that the population has a stable agewithin-stage distribution. We assumed 60 years' longevity based on the data of Kobayashi (2000) in a Cuban hawksbill population. This assumption is suppor- 
Table 2. Estimation of hawksbill's Eretmochelys imbricata managed population survivorships in the Paria region. The mortality factor is a negative percentage, while survivorship estimation is the positive fraction. On stage 1, the proportion is obtained by multiplying egg survivorship and emergence success (including poaching and predation). Assuming the worst hatchling mortality for stage 2, estimated by Harewood \& Horrocks (2008). For the rest of the stages, the proportion is the addition of fisheries (Alio et al. 2010) and stranding data. For the unmanaged population, the only difference is that survivorship of stage 1 is 0.08 .

\begin{tabular}{lccc}
\hline Stage & $\begin{array}{c}\text { Mortality factor } \\
(-)\end{array}$ & $\begin{array}{c}\text { Survivorship estimation } \\
(+)\end{array}$ & Reference \\
\hline 1. Eggs/hatchlings & $(-6.93)$ & 0.30 & Own data \\
2. Small juveniles & & 0.33 & Harewood \& Horrocks (2008) \\
3. Large juveniles & $(-0.03,-0.03)$ & 0.94 & Alió et al (2010) + strandings \\
4. Sub-adults & $(-0.02,-0.007)$ & 0.97 & Alió et al $(2010)+$ strandings \\
5. Adults & $(-0.01,-0.18)$ & 0.81 & Alió et al $(2010)+$ strandings \\
\hline
\end{tabular}
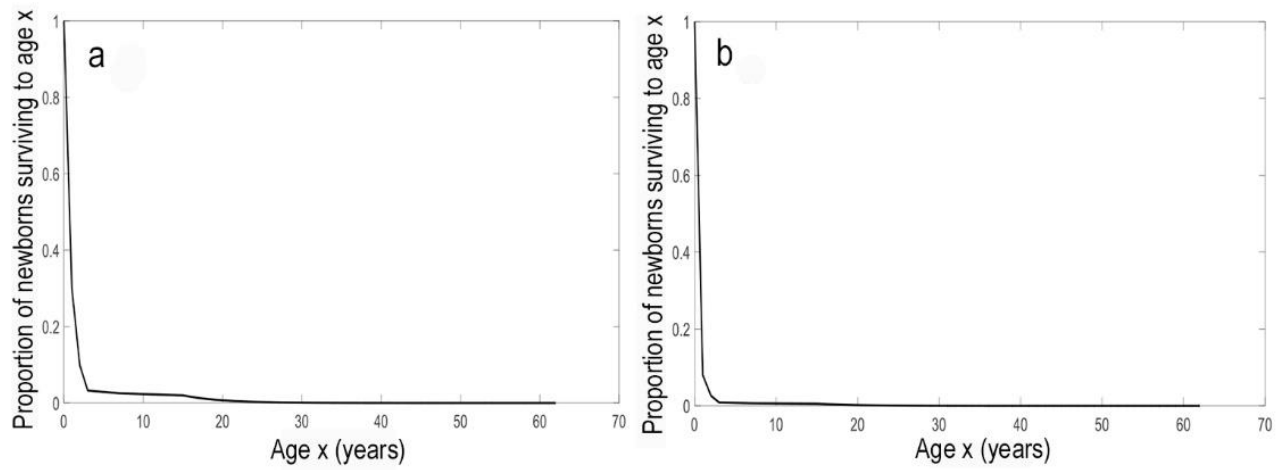

Figure 3. Age-specific survivorship profile for the a) managed and b) natural hawksbill Eretmochelys imbricata.

ted by the results of Carreras et al. (2013), who found a similar genetic composition of the mitochondrial DNA of hawksbills from Cuba and Venezuela. If $l_{x}$ is the probability of a newborn reaching age $x$, then $l_{0}=1 ; 0$ $<l_{x}<1$ for $x=1,60$; and $l_{61}=0$. With the annual mortalities of each of the stages (Table 2), the $l_{x}$ values were calculated (Fig. 3). Once the stable age distribution is reached, the population's size in the annual age interval $x$ to $x+1$ is proportional to $e^{-r x} l_{x}$, being $e$ the base of natural logarithms and $r$ the instantaneous rate of population growth. Assuming also that the population is stable in size, that is to say, $r=0$ ( or $e^{r}=\lambda=1$ ), the profile of age distribution will reflect that of $l_{x}$. Now, as an example, consider how to calculate the survivorship and growth elements corresponding to stage 3 in Table 1. This stage's annual categories go from $x=4$ to $x=7$, and the stage is composed of four annual categories. The size of the total population included in this stage when there are stable age distribution and $r=0$, is proportional to $l_{4}+l_{5}+l_{6}+l_{7}$. Now, the stage 3 fraction that stays in the same stage after a year is $\left(l_{4}+l_{5}+l_{6}\right) /\left(l_{4}+l_{5}+l_{6}+l_{7}\right)$, and the fraction that passes to the next stage is $l_{7} /\left(l_{4}+l_{5}+l_{6}+l_{7}\right)$. Multiplying these fractions by the annual survivorship of individuals in stage 3 , we obtain the values of $P_{3}$, the probability that an individual of stage 3 stays in that stage, and $G_{3}$, the probability that an individual of stage 3 passes to stage 4 .

To calculate the variance and the confidence interval of $\lambda$, we used the method of Lande (1988; see also Caswell, 2001). This method assumes that the variance of a random variable $g\left(x_{1}, x_{2}, \ldots, x_{n}\right)$, which is a function of random variables $x_{1}, x_{2}, \ldots x_{n}$, is obtained with the formula

$$
\operatorname{var}(g)=\left(\frac{\partial g}{\partial x_{1}}\right)^{2} \operatorname{var}\left(x_{1}\right)+\left(\frac{\partial g}{\partial x_{2}}\right)^{2} \operatorname{var}\left(x_{2}\right)+\ldots+\left(\frac{\partial g}{\partial x_{n}}\right)^{2} \operatorname{var}\left(x_{n}\right)
$$

being $\operatorname{var}(x)$ the variance of $x$, when the variables $x_{1}, x_{2}$, $x_{n}$ are not correlated, and these variables' deviation from their means is not large (Larsen \& Marx, 2006). Then we proceeded in two steps. First, we calculated the variances of each of the elements $A(i, j)$ of the transition matrix using Equation 2. For each element $A(i, j)$, the $x_{i}$ variables were the survivorships and fecundities, whose variances are known; also, as we know the mathematical expressions of the $A(i, j)$ 's as functions of survivorships and fecundities, we could obtain the partial derivatives in Equation 2. The second step consisted in applying Equation 2 for the dependence of $\lambda$ on the $A(i, j)$ 's; in this case, the variances of $A(i, j)$ 's 
were known from the first step, and the partial derivatives are the elements of the sensitivity matrix (Caswell, 2001).

We estimated fecundity from our field data of 64 individual nesters from 2003 to 2014 regarding clutch frequency and remigration intervals. Emergence success data were collected for managed, translocated hatchery nests from 2006 to 2016 and natural, in situ nests at the beaches with no translocation from 2003 to 2018. Missing demographic values, such as hatchling sex ratio, were estimated from the literature (Table 3, Fig. 4) (Diez \& VanDam, 2003; Hawkes et al., 2013). Data were recorded and analyzed initially in Excel (Microsoft, Redwood, Washington, USA), but mathematical processes for the transition, sensitivity, and elasticity matrices and a stable age structure curve were done with MatLab 2014.

\section{RESULTS}

This section presents the results for the managed nests (nests protected to decrease poaching and predation); and natural or unmanaged nests for when no protection action was applied.

\section{Managed nests}

The percentage of egg eclosion of managed nests was $34 \%$ (average number of nests per year $114.3 \pm 10.9$, $\mathrm{n}$ $=537$ ), due to the sensitivity of the developing sea turtle embryos to the movement (Limpus et al., 1979). Reinhold et al. (2017) have shown that low temperature can minimize the mortality of eggs due to the transportation movement in loggerhead sea turtle Caretta caretta in Australia. Protection of eggs from poaching and predation resulted in $88 \%$ of survivorship. So, the net survivorship of stage 1 in managed populations was $0.30(0.34 \times 0.88)$, as shown in Table 4. Based on our proposed model for the hawksbill turtle (Eretmochelys imbricata), most mortalities occurred on stages 1 and 2 (Table 4). In adition on slight but significant evidence, we suggest that subadults are first-time nesters in our region; however, only two nesters in this smaller size range were observed -denoted in Figure 4 with an arrow. The fecundity coefficient increased by a factor of almost three between the larger and smaller size class (Table $4)$.

Our general projection matrix with five stages is shown in Equation 1, with its corresponding life graph (Fig. 2). Our proposed projection matrices for managed and in situ nesting populations are presented (Table 5). The longest arrows (Fig. 2) are the sole two fecundities: $F_{4}$ of sub-adults with 21 , and $F_{5}$ of adults with 56.9;
Table 3. Fecundity component of the Gulf of Paria's hawksbill Eretmochelys imbricata population. Data from the conservation project. Apart we used a sex ratio of 0.67, meaning that $67 \%$ of the populations are females, with the pooled cited references.

\begin{tabular}{cccc}
\hline Stage & $\begin{array}{c}\text { Re-migrant } \\
\text { interval (years) }\end{array}$ & $\begin{array}{c}\text { Clutch } \\
\text { frequency }\end{array}$ & $\begin{array}{c}\text { Average eggs } \\
\text { number per nest }\end{array}$ \\
\hline 1 & 0 & 0 & 0 \\
2 & 0 & 0 & 0 \\
3 & 0 & 0 & 0 \\
4 & $(1 / 4)$ & 1 & 129 \\
5 & $(1 / 3)$ & 2 & 158.8 \\
\hline
\end{tabular}

these values are net fecundities, considering adult survivorship, sex ratio, remigration, and annual frequency of nesting.

The dominant eigenvalue of the transition matrix is the finite rate increase rate of the population (Caswell, 2001) and had a value of $\lambda=1.24$, which is the per capita growth rate for the managed population, and its $95 \%$ confidence interval is $(1.16,1.32)$. The $l_{x}$ curve is shown in Figure 3, looking like a type III curve (Deevey, 1947). This curve is typical of populations in which the newborn and very young individuals suffer higher mortality rates. However, once maturity is reached, the mortality considerably decreases, common life history of turtles as cited by Heppel (1998), including freshwater or terrestrial species.

The elements of matrix $E$, the elasticities, are shown (Table 6, Fig. 5). Elasticity is a more biologically meaningful value than sensitivity for it measures the proportional change of the increase rate with a given proportional change in an element of the matrix $A$. It gives instrumental measurements to compare between elements of $A$. In our case, the largest elasticities are shown by the probabilities of staying in the stage of sub-adults and adults, meaning that the most important attributes of the population, and those most critical to protect from a conservation point of view, are those probabilities.

\section{Natural nests}

For in situ nests (i.e., the natural nests not managed by the conservation effort), the average emergence success across six seasons evaluated was $64.8 \%$ (average number of nests per year $67.1 \pm 14.4, \mathrm{n}=245$ ), which is higher than that of managed turtle nests. Not patrolling the beaches resulted in poaching or predation of $88 \%$ of in situ nests in the region (Balladares \& Dubois, 2014). Accounting for this loss, overall survivorship probabilities in stage 1 for natural nests is $8 \%(0.64 \times 0.12=0.08)$. The rest of the survivorships and fecundities are the same as in managed turtles, re- 


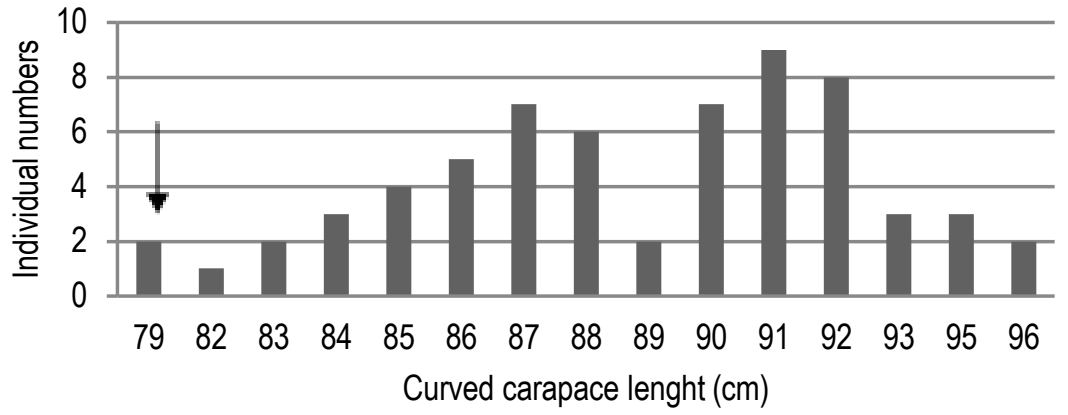

Figure 4. Curved carapace length (CCL) of 64 individual hawksbill Eretmochelys imbricata nesters over 2003 and 2014.

Table 4. General life table of the managed hawksbills Eretmochelys imbricata from the Gulf of Paria. Data pooled from tables 1,2 , and 3 . Fecundity is the number of the average eggs per female $\times 0.67 \times$ re-migrant interval $\times$ clutch frequency $x$ annual survivorship of the corresponding adult stage. For the unmanaged population, the only difference is that the survivorship of stage 1 is 0.08 .

\begin{tabular}{lccc}
\hline Stage & $\begin{array}{c}\text { Age } \\
\text { (years) }\end{array}$ & Survivorship & $\begin{array}{c}\text { Fecundity } \\
\left.\text { (eggs nest }^{-1}\right)\end{array}$ \\
\hline 1. Eggs/hatchlings & $<1$ & 0.30 & 0 \\
2. Small juveniles & $1-3$ & 0.33 & 0 \\
3. Large juveniles & $3-7$ & 0.94 & 0 \\
4. Sub-adults & $7-15$ & 0.97 & 21 \\
5. Adults & $>15$ & 0.81 & 56.9 \\
\hline
\end{tabular}

Table 5. Transition matrices of Eretmochelys imbricata a) managed and b) naturals, in the Paria Gulf.

$$
A=\left(\begin{array}{ccccc}
0 & 0 & 0 & 21 & 56.9 \\
0.30 & 0.248 & 0 & 0 & 0 \\
0 & 0.082 & 0.726 & 0 & 0 \\
0 & 0 & 0.214 & 0.97 & 0 \\
0 & 0 & 0 & 0.081 & 0.81
\end{array}\right) \quad A=\left(\begin{array}{ccccc}
0 & 0 & 0 & 21 & 56.9 \\
0.08 & 0.248 & 0 & 0 & 0 \\
0 & 0.082 & 0.726 & 0 & 0 \\
0 & 0 & 0.214 & 0.97 & 0 \\
0 & 0 & 0 & 0.081 & 0.81
\end{array}\right)
$$

Table 6. Elasticity matrices of the a) managed and b) naturals hawksbill's Eretmochelys imbricata populations in the Paria Gulf.

$a\left(\begin{array}{ccccc}0 & 0 & 0 & 0.064 & 0.033 \\ 0.097 & 0.024 & 0 & 0 & 0 \\ 0 & 0.097 & 0.138 & 0 & 0 \\ 0 & 0 & 0.097 & 0.353 & 0 \\ 0 & 0 & 0 & 0.033 & 0.062\end{array}\right) \quad b\left(\begin{array}{ccccc}0 & 0 & 0 & 0.039 & 0.029 \\ 0.068 & 0.020 & 0 & 0 & 0 \\ 0 & 0.068 & 0.129 & 0 & 0 \\ 0 & 0 & 0.068 & 0.473 & 0 \\ 0 & 0 & 0 & 0.029 & 0.077\end{array}\right)$

sulting in a transition matrix shown (Fig. 5b). This matrix's dominant eigenvalue is 1.11 , and its $95 \%$ confidence interval is $(1.04,1.18)$, meaning that a natural population has a lower per capita growth rate than a managed one. Of course, this is a consequence of a lower value of element $A(2,1)$ in the natural population. We obtained a similar type III survival curve for natural nests.

The values of $\lambda$ of both populations were larger than 1 , and this difference was statistically significant at a level of confidence of 0.05 , meaning that both populations are growing in size. The difference between the 

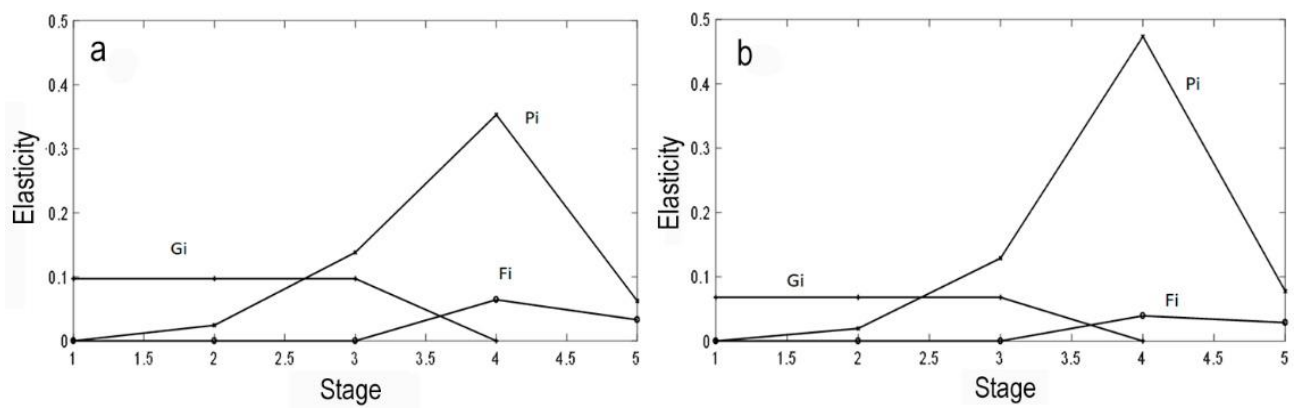

Figure 5. Elasticity graphs of the a) managed and b) natural Hawksbill's Eretmochelys imbricata populations in the Gulf of Paria.

$\lambda$ 's of the two populations is statistically significant at the 0.05 level, being that of the managed population larger than the one of the natural populations. It means that the managing and protection of the nests have increased the population growth potential.

Minor differences were noted in the elasticities for the natural population compared with the managed population (Fig. 5) due to adjustments in the population growth rate as a result of the reduced stage 1 survival. The first stage of survival increases as a result of nest management. The higher elasticity of the first stage in managed population in comparison to the natural one seems to be a consequence of higher importance of this stage once its survival has increased: the larger the probability of passing from the first stage to the second one, the larger will be the effect of a change in that survival on the rate of increase. The importance of stage 4 survival to the overall population growth rate significantly increased in the natural population compared to the managed one (Fig. 5). This difference is difficult to interpret, and we can only recommend taking it into account for management purposes.

\section{DISCUSSION}

Our study presents a five-stage population model for the hawksbill turtle (Eretmochelys imbricata) at the Gulf of Paria, Venezuela, as a reliable model for this local population. Our estimations could be the first attempt to model this population since the theoretical approach of Crouse (1999). Our initial source of regional data for large juveniles through adult stages mortality rates came from Alio et al. (2010) on the last decade of the $20^{\text {st }}$ century from the trawling fishery for shrimp before the national ban in 2002. More recent information on mortality rates for these stages was obtained from the regional stranding reports from the Venezuelan Environmental Ministry, NGOs, as well as local nature protection agencies (from 1999 to present).
Bycatch mortality differed, affecting mainly smaller size turtles than adult ones. On the contrary, stranding data reflected higher mortalities on adults than juvenile hawksbills. This last outcome affected the survivorship value of the last stage. Two possible reasons could explain these opposite results: Firstly, smaller sizes were unable to escape trawling fisheries nets than adult's size hawksbills, and secondly, smaller size hawksbills stranded could be skipped or undetected by the data collector more than the bigger size individuals. What happens on the pelagic hawksbills would require a more in-depth assessment.

The probability for eggs and hatchlings to go into the small juvenile stages for managed nests was low (0.30), approximately one third of that for later stages, and even lower for unmanaged nests (0.08). For hawksbills turtles, no comparable values exist, except from our assumed stage 2 survival (0.33) based on the work of Harewood \& Horrocks (2008) in Barbados. A similar study in Antigua Island (Reisin et al., 2015) on dispersing hatchlings showed a survival average of 0.44 between high and low predation rate areas at Pasture Bay. We used the lower value of Harewood \& Horrocks (2008) as a more conservative way to estimate survivorship at stage 2 , and because we did not have a local number of hatchlings survival after leaving the Gulf beaches.

Notwithstanding the lack of matching records for other stages, emergence success, and poaching/ predation percentage, this still represents an excellent data source of survivorship probabilities for eggs and hatchlings, as Frazer (1983) used loggerhead sea turtles. Stranding and fisheries data could be another source of survivorship in the older stages, as Van Houton et al. (2016) cited for E. imbricata from Hawaii. Additional data for juvenile hawksbill survivorship could come from in-water studies like the estimate of Strindberg et al. (2016), who estimated survivorship of 0.975 at a Caribbean atoll in Belize close in value to our calculation for this stage (0.94). 
Table 7. Comparative sea turtles survivorship rates by approximate stage.

\begin{tabular}{ccccc}
\hline \multirow{2}{*}{ Stage } & \multicolumn{4}{c}{ Region/Species } \\
\cline { 2 - 5 } & $\begin{array}{c}\text { Atlantic } \\
\text { Caretta caretta }\end{array}$ & $\begin{array}{c}\text { Mediterranean } \\
\text { C. caretta }\end{array}$ & $\begin{array}{c}\text { Hawaiian } \\
\text { Chelonia mydas }\end{array}$ & $\begin{array}{c}\text { Parian } \\
\text { Eretmochelys imbricata }\end{array}$ \\
\hline 1 & 0.67 & - & 0.35 & 0.30 \\
2 & 0.79 & - & 0.8 & $0.33 *$ \\
3 & 0.67 & - & 0.79 & 0.94 \\
4 & 0.74 & - & 0.79 & 0.97 \\
5 & 0.81 & $0.85-0.91$ & 0.79 & 0.81 \\
\hline \multirow{2}{*}{ Reference } & Crouse et al. (1987) & Casale (2011) & Van Houton et al. (2014) & Balladares et al. (this study) \\
& Heppell (1998) & & & *Harewood \& Horrocks (2008) \\
\hline
\end{tabular}

In Table 7, we show a comparison between estimates of survivorship at different stages of other sea turtle species and this study, noticing that the two first stages of hawksbills at the Gulf have lower survivorship than other species.

Avens \& Snover (2013) mentioned a late fecundity starting from 17 years old for hawksbills turtles based on the osteological analysis. To obtain information on fecundity at the studied rookery, we estimated that reproduction started with the sub-adults of more than seven years of age, based on our observations of the nesting behavior of 64 individuals at the Gulf of Paria and following the recent research of Hawkes et al. (2014). According to the former authors, E. imbricata presents a high growth rate of almost $20.3 \mathrm{~cm} \mathrm{yr}^{-1}$ in the Caribbean British Virgin Island of Anegada, which allows this species to reach sexual maturity in less time than loggerheads (>25 years, Frazer \& Ehrhart, 1985) or Kemp's ridleys (Lepidochelys kempi) (>15, Chaloupka \& Zug, 1997). This early breeding pattern has also been observed in other parts of the Caribbean with hawksbills between 60 and $80 \mathrm{~cm}$ of curved carapace length (Moncada et al., 1999).

The finite population growth rate of the hawksbill managed population in the region is 1.24 , which is larger than those in other species and places such as the USA's loggerhead (0.942), and green turtles (0.945) for loggerhead but with a stage 7 matrix (Crouse et al., 1987). Regarding the natural population of the hawksbill turtles in the Gulf of Paria, this rate was 1.11, which, although larger than 1 , is still a low rate of increase typical of populations of organisms with high longevity.

From our study at this hawksbill population in the Gulf, the survival probability represents a high risk of loss to the eggs and hatchlings -even more so considering the lack of protection for in situ nests. In that sense, we recommend the protection of stage 1 and be subject of conservation efforts in the area. Additionally, we obtained similar patterns to Crouse et al. (1987), Crowder et al. (1994), and Heppell et al. (1996) in loggerhead sea turtles, who have found a high elasticity in the survival of later stages. Thus, protecting the survivorship of sub-adults and adults should be an essential conservation policy for sea turtles. We also encourage further local studies to improve estimations of survivorships in stage 2, at least for the first hours in the open waters, applying the Harewood \& Horrocks (2008) technique, or using new telemetry for neonates such as the investigations of Mansfield et al. (2014, 2017). The latter gives us an estimation of almost the first year, as well as the carapace notching of hatchlings that have provided an estimation of survivorship to first breeding in Caretta caretta and Chelonia mydas in south Queensland (Limpus et al., 2019).

Finally, according to our fisheries and stranding data of the eastern Venezuelan coast, the last three stages showed survivorship of $>0.81$, which could be explained by the mortality of adults observed from the stranding information. Regarding fecundity in the last two stages, this must be a possible warrant for early reproduction, which could contribute to the fast recovery of the species in this region, particularly for subadults stages. The elasticity measurements highlight the importance of alterations to survival in these last two stages for changes in the growth rate, in comparison to the parameters of other stages. However, more tagging and reproductive monitoring must be done in the Gulf of Paria in order to confirm our stage 4 results.

\section{ACKNOWLEDGMENTS}

The first author wants to thank all the friends at Macuro, the Venezuelan Ministry of the Environment for the initial funds, the park rangers from Inparques, and the help from Conoco-Phillips, Timberland de Venezuela during the last three seasons, volunteers, and personal donors like the late Saul Gutierrez. Our appreciation to Juan Carlos Amilibia and Rodrigo Lazo for the map. Our thanks to the professors of Universidad Central de Venezuela and Jose Alio for the 
early review of the first draft. Finally, to Dr. Matthew Ware from the Florida State University, who made a pervasive review of the manuscript, and Hector Barrios from La Universidad del Zulia, who made this contact possible.

\section{REFERENCES}

Alió, J., Marcano, L. \& Altuve, D. 2010. Incidental capture and mortality of sea turtles in the industrial shrimp trawling fishery of northeastern Venezuela. Ciencias Marinas, 36: 161-178.

Avens, L. \& Snover, M.L. 2013. Age and age estimation in sea turtles. In: Wyneken, J., Lohmann, K. \& Musick, J.A. (Eds.). The biology of sea turtles. CRC Press, Boca Raton, pp. 97-134.

Balladares, C., Cova, L. \& Mata, N. 2010. Heridas causadas por depredadores naturales e interacciones humanas sobre tortugas marinas anidantes en playa Los Garzos (Estado Sucre, Venezuela). Boletín del Instituto Oceanográfico de Venezuela, 49: 123-128.

Balladares, C. \& Dubois, E. 2014. Saqueo y depredación de nidadas de tortugas marinas, durante las temporadas 2003 a 2012, en seis playas del Golfo de Paria, Venezuela. Cuadernos de Investigación UNED, 6: 239-243.

Barrios-Garrido, H., Espinoza-Rodríguez, N., RojasCañizales, D., Palmar, J., Wildermann, N., MontielVillalobos, M.G. \& Hamann, M. 2017. Trade of marine turtles along the southwestern coast of Venezuela. Marine Biodiversity Records, 10: 15.

Beggs, J., Horrocks, J. \& Krueger, B. 2007 Increase in hawksbill sea turtle Eretmochelys imbricata nesting in Barbados, West Indies. Endangered Species Research, 3: $159-168$.

Carreras, C., Godley, B., León, Y., Hawkes, L., Revuelta, O., et al. 2013. Contextualizing the last survivors: population structure of marine turtles in the Dominican Republic. Plos One, 8(6): e66037. doi:10.1371/journal.pone. 0066037

Casale, P. 2011. Sea turtle bycatch in the Mediterranean. Fish and Fisheries, 12: 299-316.

Caswell, H. 2001. Matrix population models. Sinauer Associates Publishers, Massachusetts.

Chaloupka, M. \& Zug, G. 1997. A polyphasic growth function for the endangered Kemp's Ridley Sea Turtle. Fishery Bulletin, 95: 849-856.

Crouse, D. 1999. Population modeling and implications for Caribbean hawksbill sea turtle management. Chelonian Conservation and Biology, 3: 185-188.

Crouse, D., Crowder, L. \& Caswell, H. 1987. A stagebased population model for loggerhead sea turtles and implications for conservation. Ecology, 68: 14121423.

Crowder, L., Crouse, D., Heppell, S. \& Martin, T. 1994. Predicting the impact of turtle excluder devices on loggerhead sea-turtle populations. Ecological Applications, 4: 437-445.

Deevey, E.S. 1947. Life tables for natural populations of animals. Quarterly Review of Biology, 22: 283-314. doi:10.1086/395888

Diez, C. \& Van Dam, R. 2003. Sex ratio of an immature hawksbill sea turtle aggregation at Mona Island, Puerto Rico. Journal of Herpetology, 37: 533-537.

Eckert, K.L., Bjorndal, K.A., Abreu-Grobois, F.A. \& Donnelly, M. (Eds.). 2000. Técnicas de investigación y manejo para la conservación de las tortugas marinas. Grupo Especialista en Tortugas Marinas UICN/CSE, Gland.

Frazer, N. 1983. Survivorship of adult female loggerhead sea turtles, Caretta caretta, nesting on Little Cumberland Island, Georgia, USA. Herpetologica, 39: 436-447.

Frazer, N. \& Ehrhart, L. 1985. Preliminary growth models for green, Chelonia mydas, and loggerhead, Caretta caretta, turtles in the wild. Copeia, 1: 73-79.

Gorham, J., Clark, D., Bresette, M., Bagley, D., Keske C., et al. 2014. Characterization of a subtropical hawksbill sea turtle (Eretmochelys imbricata) assemblage utilizing shallow-water natural and artificial habitats in the Florida Keys. Plos One 9: e114171. doi:10.1371/ journal.pone.0114171

Hawkes, L., McGowan, A., Broderick, A., Gore, S., Wheatley, D., White, J., et al. 2014. High rates of growth recorded for hawksbill sea turtles in Anegada, British Virgin Islands. Ecology and Evolution 4: 12551266.

Hawkes, L., McGowan, A., Godley, B., Shannon, S., Lange, A., Tyler, C., et al. 2013. Estimating sex ratios in Caribbean hawksbill turtles: testosterone levels and climate effects. Aquatic Biology, 18: 9-19.

Hawkes, L., Tomás, J., Revuelta, O., León, Y., Blumenthal, J., Broderick, A., et al. 2012. Migratory patterns in hawksbill turtles described by satellite tracking. Marine Ecology Progress Series, 461: 223232.

Hamilton, R., Bird, T., Gereniu, C., Pita, J., Ramohia, P., Walter, R., et al. 2015. Solomon Islands' largest hawksbill turtle rookery shows signs of recovery after 150 years of excessive exploitation. Plos One, 10: e0121435. doi:10.1371/journal.pone.0121435

Harewood, A. \& Horrocks, J. 2008. Impacts of coastal development on hawksbill hatchling survival and 
swimming success during the initial offshore migration. Biological Conservation, 141: 394-401.

Heppel, S., Limpus, C., Crouse, D., Frazer, N. \& Crowder, L. 1996. Population model analysis for the loggerhead sea turtle, Caretta caretta, in Queensland. Wildlife Research, 23: 143-159.

Heppel, S. 1998. Application of life-history theory and population model analysis to turtle conservation. Copeia, 1998(2): 367-375.

Herrera, I.M., Hernández, M., Lampo, M. \& Nassar, J. 2012. Plantlet recruitment is the key demographic transition in invasion by Kalanchoe daigremontiana. Population Ecology, 54: 225-237.

Kobayashi, M. 2000. An analysis of the growth based on the size and age distributions of the hawksbill sea turtle inhabiting Cuban waters. Japanese Journal of Veterinary Research, 48: 129-135.

Lande, R. 1988. Demographic models of the northern spotted owl (Strix occidentalis caurina). Oecologia, 75: 601-607.

Larsen, R.J. \& Marx, M.L. 2006. An introduction to mathematical statistics and its applications. Pearson Prentice Hall, New Jersey.

Limpus, C. 2000. Final report for Australian hawksbill turtle population dynamics Project. EPA, Queensland, $141 \mathrm{pp}$.

Limpus, C., Baker, V. \& Miller, J. 1979. Movement induced mortality of loggerhead eggs. Herpetologica, 35: 335-338.

Limpus, C., Ferguson, J., FitzSimmons, N.N., Limpus, D.J. \& Sergeev, J.M. 2019. Recommencing the tagging of flatback turtle, Natator depressus, hatchlings using carapace notching. Marine Turtle Newsletter, 157: 1-4.

Mansfield, K., Wyneken, J., Porter, W. \& Luo, J. 2014 First satellite tracks of neonate sea turtles redefine the 'lost years' oceanic niche. Proceedings of the Royal Society, 281(1781): 20133039. doi: 10.1098/rspb. 2013.3039

Mansfield, K.L., Mendilaharsu, M.L., Putman, N.F., dei Marcovaldi, M.A.G., Sacco, A.E., Lopez, G., et al. 2017. First satellite tracks of South Atlantic sea turtle 'lost years': seasonal variation in trans-equatorial movement. Proceedings of the Royal Society, 284(1868): 29212722. doi: 10.1098/rspb.2017.1730

Received: 29 November 2019; Accepted: 5 June 2020
Moncada, F., Carrillo, E., Sáenz, A. \& Nodarse, G. 1999. Reproduction and nesting of the hawksbill turtle (Eretmochelys imbricata) in the Cuban Archipelago. Chelonian Conservation and Biology, 3: 257-263.

Moncada, F., Hawkes, L., Fish, M., Godley, B., Manolis, S., Medina, Y., et al. 2012. Patterns of dispersal of hawksbill turtles from the Cuban shelf inform scale of conservation and management. Biological Conservation, 148: 191-199.

Morris, J., Shertzer, K. \& Rice, J. 2011. A stage-based matrix population model of invasive lionfish with implications for control. Biological Invasions, 13: 712.

Mortimer, J.A. \& Donnelly, M. 2008. Eretmochelys imbricata. IUCN red list of threatened species. [https://www.iucnredlist.org/species/8005/12881238]. Reviewed: April 06, 2019.

Reinhold, L., Limpus, C.J., Limpus, D.J. \& Whiting, A.U. 2017. Pivotal temperature of loggerhead sea turtles, Caretta caretta, from Dirk Hartog Island, Western Australia. Memoirs of the Queensland MuseumNature, 60: 161-171.

Reising, M., Salmon, M. \& Stapleton, S. 2015. Hawksbill nest site selection affects hatchling survival at a rookery in Antigua, West Indies. Endangered Species Research, 29: 179-187.

Richardson, J.I., Hall, D.B., Mason, P.A., Andrews, K.M., Bjorkland, R., Cai, Y. \& Bell, R. 2006. Eighteen years of saturation tagging data reveal a significant increase in nesting hawksbill sea turtles (Eretmochelys imbricata) on Long Island, Antigua. Animal Conservation, 9: 302-307. doi:10.1111/j.1469-1795.2006. 00036.x

Rincón, F., Astor, Y., Muller-Karger, F., Varela, R. \& Odriozola, A. 2008. Características oceanográficas del flujo en Boca de Dragón, Venezuela. Memoria de la Fundación La Salle de Ciencias Naturales, 168: 7-24.

Strindberg, S., Coleman, R.A., Burns-Perez, V.R., Campbell, C.L., Majil, I. \& Gibson, J. 2016. In-water assessments of sea turtles at Glover's Reef Atoll, Belize. Endangered Species Research, 31: 211-225.

Vam Dam, R., \& Diez, C. 1998. Caribbean hawksbill turtle morphometrics. Bulletin of Marine Science, 62: 145-155.

Witzell, W.N. 1983. Synopsis of biological data on the hawksbill turtle Eretmochelys imbricata (Linnaeus, 1766). FAO Fisheries Synopses, 137: 78 pp. 